\title{
PENGARUH WAKTU EKSTRAKSI DAN KONSENTRASI ETANOL MENGGUNAKAN METODE MICROWAVE ASSISTED EXTRACTION (MAE) TERHADAP AKTIVITAS ANTIOKSIDAN EKSTRAK RAMBUT JAGUNG (Zea mays L.)
}

Effect of Extraction Time and Ethanol Concentration with Microwave Assisted Extraction (MAE) of Antioxidant Activity Corn Silk Extract (Zea mays.L.).

\author{
Yessica Kristanti ${ }^{1)}$, I Wayan Rai Widarta ${ }^{2)}$, I Dewa Gede Mayun Permana ${ }^{3)}$ \\ ${ }^{1)}$ Mahasiswa Program Studi Imu dan Teknologi Pangan, Fakultas Teknologi Pertanian, Unud \\ ${ }^{2}$ Dosen Program Studi Imu dan Teknologi Pangan, Fakultas Teknologi Pertanian, Unud \\ Kampus Bukit Jimbaran, Badung-Bali
}

\begin{abstract}
This research was conducted to determine effect of the extraction time and ethanol concentration on antioxidant activity of corn silk extract and to obtain extraction time and ethanol concentration using Microwave Assisted Extraction (MAE) that can produce extract with the highest antioxidant activity. The experimental design used in this research was a completely randomize design, which consisted of two factors. The fisrt factor was the concentration of ethanol which consisted of 5 level that namely ethanol 30\%, 45\%, 60\%, 75\%, and 90\%. The second factor was the time of extraction which consisted of 3 level namely 8, 13 and 18 minutes. Data were analyzed with analysis of variance that followed by Duncan test. The result showed that the best treatment of corn silk extract is extraction by ethanol $90 \%$ for 18 minutes using MAE which the highest resulted rendemen was 24.54\%, total phenol was $159.65 \mathrm{mg}$ GAE/g extract, total flavonoid was $149 \mathrm{mgQE} / \mathrm{g}$ extract, antioxidant activity was $70.18 \%$, and the $I C_{50}$ value $64.806 \mathrm{ppm}$.
\end{abstract}

Keyword : corn silk, MAE, ethanol, antioxidant activity

\section{PENDAHULUAN}

Jagung merupakan salah satu pangan pokok yang dikonsumsi di Indonesia. Jagung memiliki kandungan karbohidrat yang tinggi (19\%) sehingga seringkali digunakan sebagai pangan sumber karbohidrat pengganti nasi (Purwanto, 2008). Menurut data dari Badan Pusat Statistik (BPS) produksi jagung nasional tahun 2013 mencapai 18,5 juta ton dan pada tahun 2015 meningkat menjadi 19,6 juta ton. Hasil bulir jagung yang dimanfaatkan dalam bidang pangan hanya mewakili 5\% dari keseluruhan tanaman jagung, sedangkan 95\% sisa dari tanaman jagung dimasukkan dalam kategori limbah alami yaitu batang, daun, kulit, rambut dan tongkol jagung (Faesal, 2013). Salah satu limbah tanaman jagung yang belum termanfaatkan secara optimal adalah rambut jagung yaitu 5\% dari satu tongkol jagung.

Rambut jagung digunakan oleh beberapa masyarakat sebagai obat herbal. Pemanfaatkan air rebusan rambut jagung adalah untuk mengobati dan mencegah beberapa penyakit. Rambut jagung sering dimanfaatkan sebagai pengobatan herbal untuk hipertensi, tumor, hiperglikemia, hepatitis, sistitis, batu ginjal, diabetes, nephritis, dan penyakit prostat (Hu dan Deng, 2011). Pemanfaatan air rambut jagung dapat diperoleh dengan merebus rambut jagung

*Korespondensi Penulis:

Email:rai_widarta@yahoo.com ${ }^{1)}$ 
tersebut atau dengan merendamnya semalaman (Herbie, 2015).

Rambut jagung dinyatakan sebagai sumber dari banyak komponen bioaktif diantaranya adalah senyawa volatil, steroid, alkaloid, dan antioksidan alami seperti flavonoid dan senyawa fenolik lainnya dengan manfaat yang menguntungkan bagi kesehatan manusia (Liu et al., 2011). Bushman (2002) menyatakan bahwa rambut jagung juga mengandung saponin, tanin, asam klorogenik, fitosterol, allantoin dan senyawa berharga lainnya. Sarepoua et al.(2013) melaporkan bahwa rambut jagung yang dimaserasi dengan menggunakan pelarut etanol $95 \%$ menghasilkan ekstrak rambut jagung yang mengandung total fenolik, total flavonoid, dan aktivitas antioksidan masing-masing sebesar $117,1 \mu \mathrm{g}$ GAE/g, 88,8 $\mu \mathrm{g}$ GAE/g, dan 75,6\%. Secara umum rambut jagung mengandung $17,6 \%$ protein, 0,29\% lemak, 3,91\% kadar abu, dan $40 \%$ serat pangan (Wang et al., 2011).

Salah satu cara untuk memperoleh senyawa bioaktif adalah dengan cara ekstraksi. Metode ekstraksi salah satunya adalah dengan teknik MAE (Microwave Assisted Extraction). Teknik Ekstraksi MAE merupakan teknik ekstraksi yang memanfaatkan radiasi gelombang mikro untuk memanaskan pelarut secara cepat dan efisien (Jain, 2009). Ekstraksi MAE juga sangat cocok digunakan untuk mengekstraksi senyawa yang tidak tahan terhadap panas. Metode MAE juga dapat membantu meningkatkan jumlah rendemen ekstrak kasar dalam waktu ekstraksi dan jumlah pelarut yang lebih rendah dibanding dengan metode ekstraksi konvensional (Langat, 2011). Panas radiasi gelombang mikro ini dapat memanaskan dan menguapkan air pada sel sampel sehingga tekanan pada dinding sel meningkat dan mengakibatkan sel membengkak (swelling) dan tekanan tersebut mendorong dinding sel dari dalam, meregangkan, dan memecahkan sel tersebut
(Alupululai (2012) dalam Fadhli, 2013). Rusaknya sel tumbuhan tersebut mempermudah senyawa target keluar dan terekstraksi (Jain, 2009).

Beberapa faktor yang mempengaruhi ekstraksi dengan teknik MAE adalah ukuran bahan, suhu, waktu, dan pelarut. Waktu ekstraksi memiliki pengaruh yang besar terhadap ekstraksi, waktu ekstraksi yang terlalu lama atau terlalu singkat dapat mempengaruhi sifat fisik dan kimia dari bahan yang terekstrak. Kojic et al. (2011) melaporkan bahwa suhu dan waktu ekstraksi memiliki peranan yang penting dalam ekstraksi senyawa fenolik. Terlalu singkatnya waktu ekstraksi mengakibatkan pelarutan senyawa fenolik tidak optimum sehingga bahan belum terekstraksi secara sempurna dan sebaliknya, semakin lama waktu ekstraksi maka akan menaikan jumlah analit yang terekstrak karena kontak antara pelarut dengan zat terlarut akan semakin lama sehingga proses pelarutan senyawa fenolik akan terus berlangsung dan berhenti sampai pelarut jenuh. Namun, ketika waktu optimum telah tercapai, penambahan waktu ekstraksi tidak lagi dapat meningkatkan kandungan senyawa fenolik yang terekstrak (Ince et al., 2013). Graziani et al. (2011) melaporkan bahwa ekstraksi tanaman Crocus sativus dengan microwave selama 18 menit menghasilkan aktivitas antioksidan yang lebih tinggi dibandingkan ekstraksi menggunakan gelombang ultrasonik selama 30 menit.

Kecocokan pelarut untuk ekstraksi bahan dinilai dari kepolaran bahan yang akan diekstraksi. Etanol atau etil alkohol $\left(\mathrm{C}_{2} \mathrm{H}_{6} \mathrm{O}\right)$ termasuk kelompok hidroksil yang memberikan polaritas pada molekul dan mengakibatkan meningkatnya ikatan hidrogen intermolekuler (Kirk dan Othmer, 2006). Flavonoid adalah polifenol yang bersifat polar sehingga akan lebih mudah larut dalam pelarut yang polar (Handayani et al., 2014). Berbagai konsentrasi pelarut yang digunakan akan mengakibatkan perubahan polaritas 
sehingga mempengaruhi kelarutan flavonoid (Zhang et al., 2009 dalam Widarta dan Arnata, 2017). Handayani et al. (2014) menyatakan bahwa semakin tinggi konsentrasi etanol maka rendemen ekstrak yang dihasilkan akan semakin tinggi, namun kadar polifenol mencapai optimum pada konsentrasi etanol tertentu. Penelitian ini bertujuan untuk mengetahui pengaruh waktu ekstraksi dan konsentrasi etanol terhadap total fenol, flavonoid dan aktivitas antioksidan pada ekstrak rambut jagung dan juga mengetahui perlakuan yang tepat untuk mendapatkan aktivitas antioksidan tertinggi.

\section{METODE PENELITIAN}

\section{Tempat dan Waktu}

Penelitian ini dilaksanakan di Laboratorium Pengolahan Pangan dan Laboratorium Analisis Pangan, Program Studi Ilmu dan Teknologi Pangan, Fakultas Teknologi Pertanian, Universitas Udayana, Kampus Sudirman, Denpasar. Penelitian ini dilakukan pada bulan Maret-Mei 2018.

\section{Bahan dan Alat}

Bahan yang digunakan dalam penelitian ini adalah rambut jagung manis muda yang berasal dari penjual jagung bakar di Tuban, Bali dengan usia 1 hari sejak pemisahan dari tongkol jagung dan dipanen sekitar 70 hari dari masa berbunga. Bahan kimia yang digunakan terdiri dari Aquades, etanol, reagen Folin-Ciocalteu, $\mathrm{NaNO}_{2}, \mathrm{AlCl}_{3}, \mathrm{Na}_{2} \mathrm{CO}_{3}, 1,1$ diphenyl-2-picrylhydrazil (DPPH).

Alat yang digunakan adalah blender (philips), evaporator vakum (Ika Labortechnik), microwave (samsung), kertas saring Whatman no 1 , seperangkat alat gelas (pyrex dan iwaki), oven (cosmos), spektrofotometer UV-VIS (Genesys 10s UvVis), pipet volume (pyrex), timbangan analitik (Shimadzu), ayakan 40 mesh, dan alumunium foil.

\section{Rancangan Penelitian}

Penelitian ini menggunakan rancangan acak lengkap (RAL) pola faktorial dengan perlakuan konsentrasi etanol dan waktu ekstraksi. Faktor pertama adalah konsentrasi etanol (P) terdiri dari etanol 30\% (P1), 45\% (P2), 60\% (P3), 75\% (P4) dan 90\% (P5) sedangkan faktor kedua adalah waktu ekstraksi (W) terdiri dari 8 menit (W1), 13 menit (W2) dan 18 menit (W) sehingga diperoleh 15 perlakuan. Perlakuan ini diulang sebanyak dua kali sehingga diperoleh 30 unit percobaan. Data yang diperoleh dianalisis menggunakan sidik ragam (ANOVA). Perlakuan yang berpengaruh nyata dianalisis dengan uji Duncan (Steel dan Torrie, 1993).

\section{Pelaksanaan Penelitian \\ Persiapan Sampel}

Rambut jagung dipisahkan dari tongkol jagung dan kulitnya, kemudian rambut jagung yang sudah disortasi dikeringkan dengan oven pada suhu $60^{\circ} \mathrm{C}$ selama 6 jam. Setelah itu, rambut jagung digiling sehingga menghasilkan serbuk kasar dan kemudian diayak menggunakan ayakan 40 mesh. Proses pembuatan bubuk rambut jagung dapat dilihat pada Gambar 1.

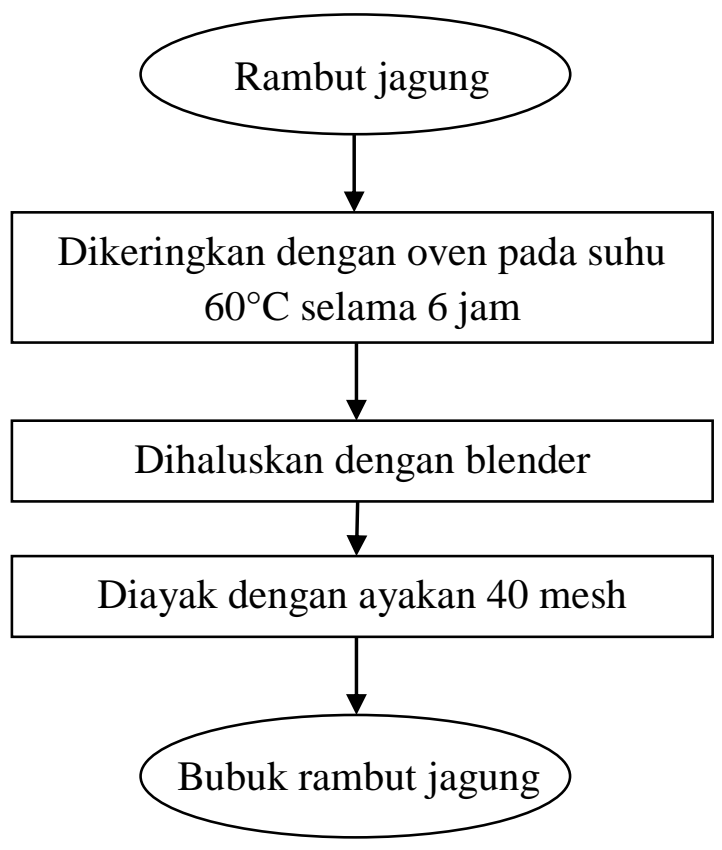


Gambar 1. Proses pembuatan bubuk rambut jagung (Hu et al., (2010), yang dimodifikasi)

\section{Proses ekstraksi rambut jagung}

Bubuk rambut jagung sebanyak 15 gram dilarutkan dengan pelarut etanol dengan konsentrasi 30\%, 45\%, 60\%, 75\%, dan 90\% sesuai perlakuan sebanyak $225 \mathrm{ml}$ (1:15 $\mathrm{g} / \mathrm{ml})$, dilakukan pengadukan dan didiamkan selama 20 menit. Dilakukan proses ekstraksi menggunakan microwave dengan waktu sesuai perlakuan yaitu selama 8,13 , dan 18 menit sesuai perlakuan dengan daya $450 \mathrm{~W}$. Hasil ekstraksi disaring menggunakan kertas saring Whatman no 1 sehingga menghasilkan filtrat. Filtrat hasil penyaringan dilakukan pemekatan menggunakan rotary vacuum evaporator dengan tekanan $100 \mathrm{mBar}$, suhu $40^{\circ} \mathrm{C}$ dan putaran 60rpm. (Handayani et al., 2013).

\section{HASIL DAN PEMBAHASAN}

\section{Rendemen}

Hasil sidik ragam menunjukkan bahwa interaksi waktu ekstraksi dan konsentrasi etanol pada ekstrak rambut jagung berpengaruh sangat nyata $(\mathrm{P}<0,01)$ terhadap rendemen ekstrak rambut jagung. Grafik interaksi antara waktu ekstraksi dan konsentrasi etanol terhadap rendemen ekstrak rambut jagung dapat dilihat pada Gambar 2.

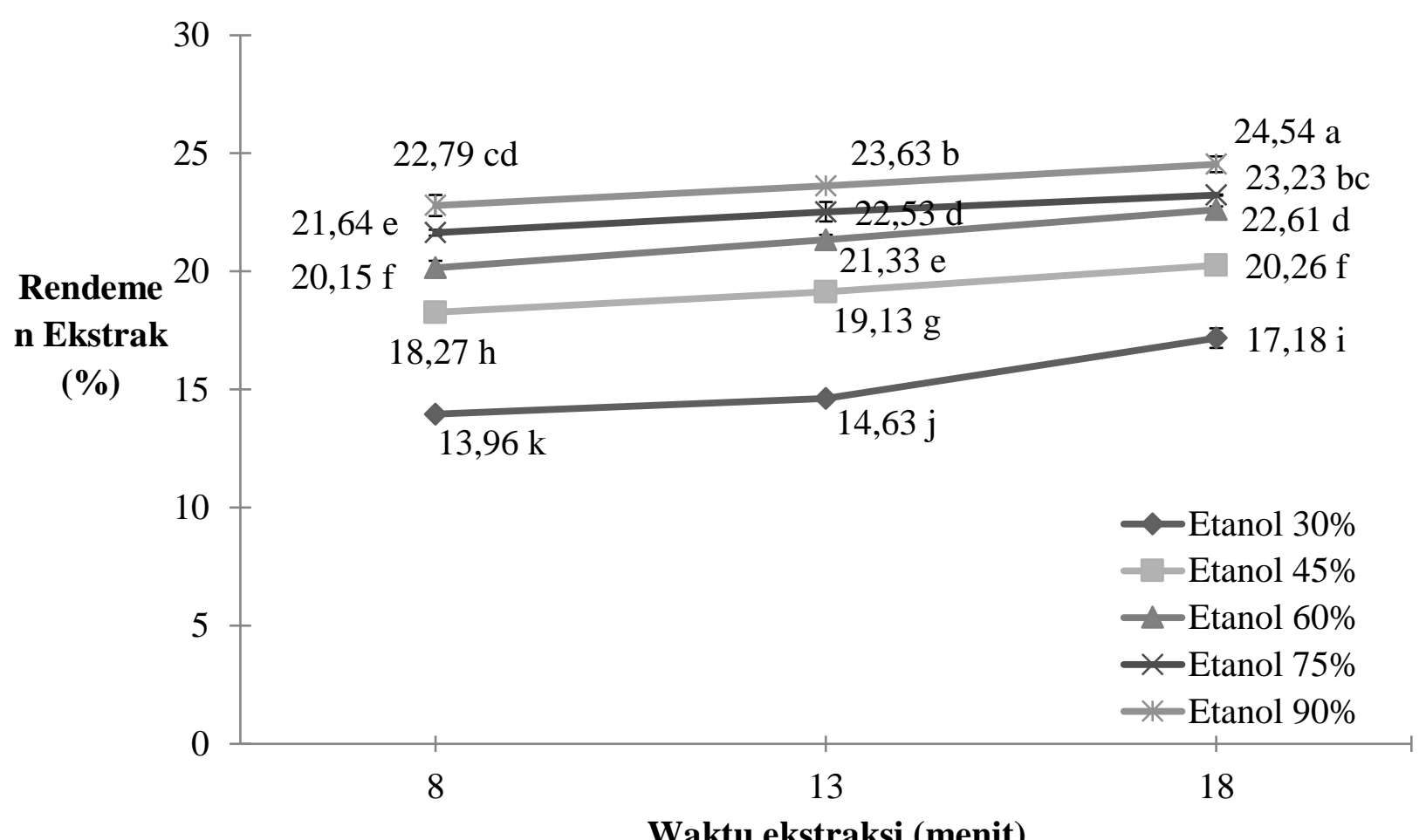

Waktu ekstraksi (menit)

Gambar 2. Rendemen ekstrak rambut jagung (\%)

Keterangan: Notasi yang sama menunjukkan perlakuan tidak berbeda nyata $(\mathrm{P}>0,05)$

Berdasarkan Gambar 2 dapat dilihat bahwa rendemen terbesar diperoleh dari hasil ekstraksi dengan etanol 90\% dengan waktu 18 menit yaitu sebesar $24,54 \%$ sedangkan rendemen terendah diperoleh dari hasil ekstraksi dengan etanol $30 \%$ dengan waktu 8 menit yaitu $13,96 \%$. Hal tersebut menyatakan bahwa semakin tinggi konsentrasi etanol dan semakin lama waktu ekstrasi maka akan meningkatkan rendemen ekstrak rambut jagung. 
Konsentrasi etanol mempengaruhi polaritas etanol yang digunakan. Kesesuaian polaritas pelarut dengan senyawa yang akan dilarutkan memaksimalkan ekstraksi yang dilakukan. Handayani et al., (2014) menyatakan bahwa semakin tinggi konsentrasi etanol maka rendemen ekstrak yang dihasilkan akan semakin tinggi.

Semakin lama waktu ekstraksi akan meningkatkan jumlah rendemen ekstrak rambut jagung. Handayani et al., (2014) menyatakan bahwa semakin lama waktu ekstraksi maka kesempatan bahan kontak dengan pelarut akan semakin besar sehingga rendemen hasil ekstraksi juga akan bertambah.

\section{Total Fenol}

Hasil sidik ragam menunjukkan bahwa interaksi waktu ekstraksi dan konsentrasi etanol dalam ekstraksi rambut jagung berpengaruh sangat nyata $(\mathrm{P}<0,01)$ terhadap total fenol. Grafik hasil interaksi antara konsentrasi etanol dan waktu ekstraksi terhadap total fenol pada ekstrak rambut jagung dapat dilihat pada Gambar 3.

Gambar 3 menunjukkan bahwa total fenol tertinggi diperoleh dari ekstraksi dengan etanol 90\% dengan waktu 18 menit yaitu $159,39 \mathrm{mg} \mathrm{GAE} / \mathrm{g}$ ekstrak, sedangkan total fenol terendah diperoleh dari ekstraksi dengan etanol 30\% dengan waktu 8 menit yaitu 75,41 mg GAE/g ekstrak.

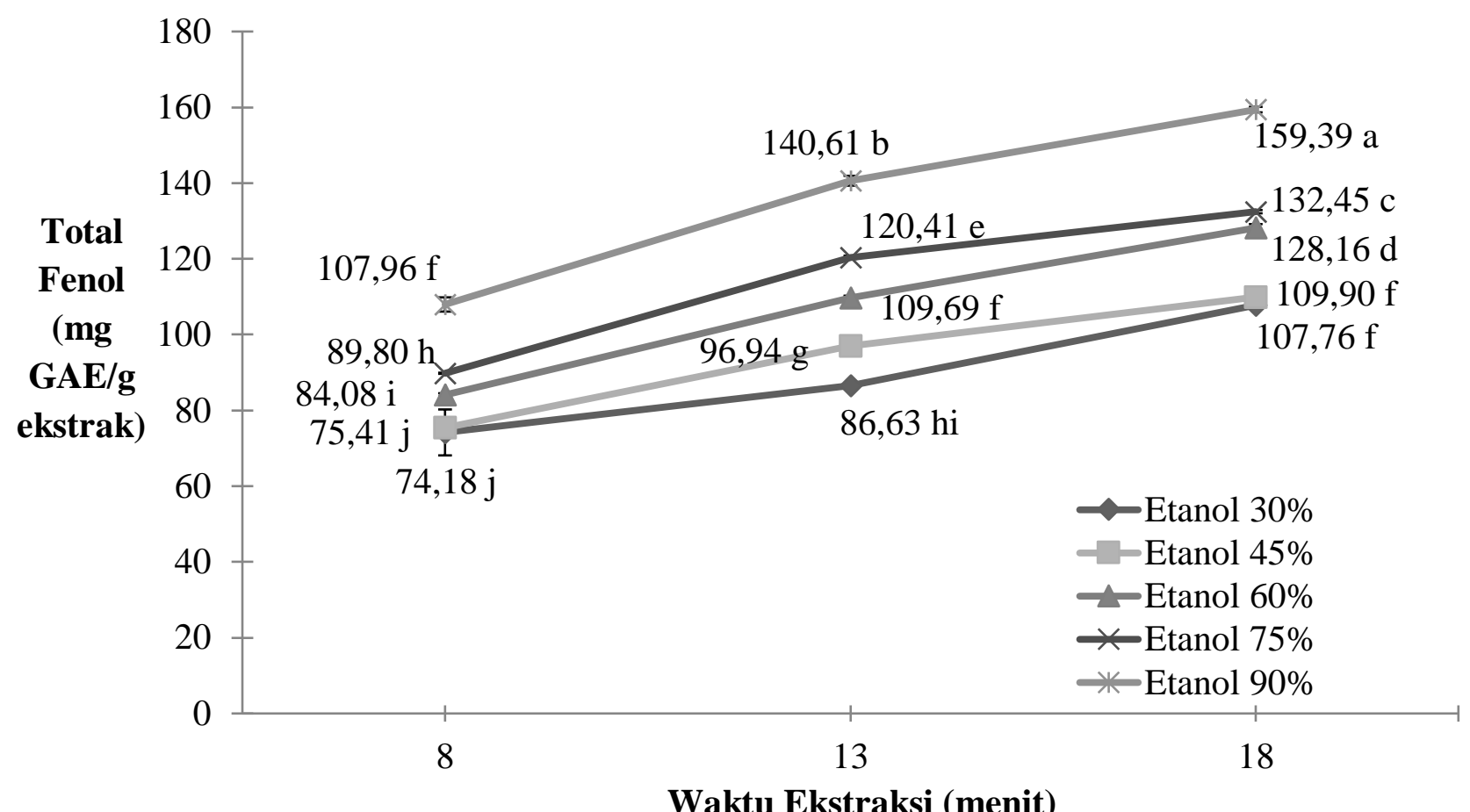

Gambar 4. Total fenol ekstrak rambut jagung (mg GAE/g ekstrak)

Keterangan: Notasi yang sama menunjukkan perlakuan tidak berbeda nyata $(\mathrm{P}>0,05)$

Kenaikan waktu proses ekstraksi yang digunakan akan meningkatkan penetrasi pelarut ke dalam bahan sehingga pelarut semakin mudah untuk menarik zat-zat kimia keluar dari bahan, sementara semakin sedikitnya waktu ekstraksi yang digunakan akan mempersulit pelarut untuk menembus dinding-dinding pada bahan (Tambun et al., 
2016). Pada ekstraksi lengkuas merah menggunakan pelarut etanol $96 \%$ juga didapatkan bahwa kandungan total fenol semakin meningkat seiring dengan semakin lama waktu ekstraksi sampai titik optimum (Tambun et al., 2016). Waktu ekstraksi terbaik pada penelitian ini adalah 18 menit. Hal serupa juga dilaporkan oleh Graziani et al., (2010) yang menyatakan bahwa waktu 18 menit juga merupakan waktu optimum untuk memperoleh total fenol terbaik pada Crocus sativus.

Konsentrasi etanol yang meningkat mengakibatkan polaritas pelarut yang menurun akan meningkatkan total fenol. Handayani et al., (2014) menyatakan bahwa kesesuaian polaritas pelarut dengan bahan akan meningkatkan proses ekstraksi pada bahan. Nisa et al., (2014) menyatakan bahwa pada ekstraksi daun sirih merah, kenaikan konsentrasi etanol berbanding lurus dengan total fenol yang diperoleh.

\section{Total Flavonoid}

Hasil sidik ragam menunjukkan bahwa interaksi waktu ekstraksi dan konsentrasi etanol dalam ekstraksi rambut jagung berpengaruh sangat nyata $(\mathrm{P}<0,01)$ terhadap total flavonoid. Grafik hasil interaksi antara konsentrasi etanol dan waktu ekstraksi terhadap total flavonoid pada ekstrak rambut jagung dapat dilihat pada Gambar 4.

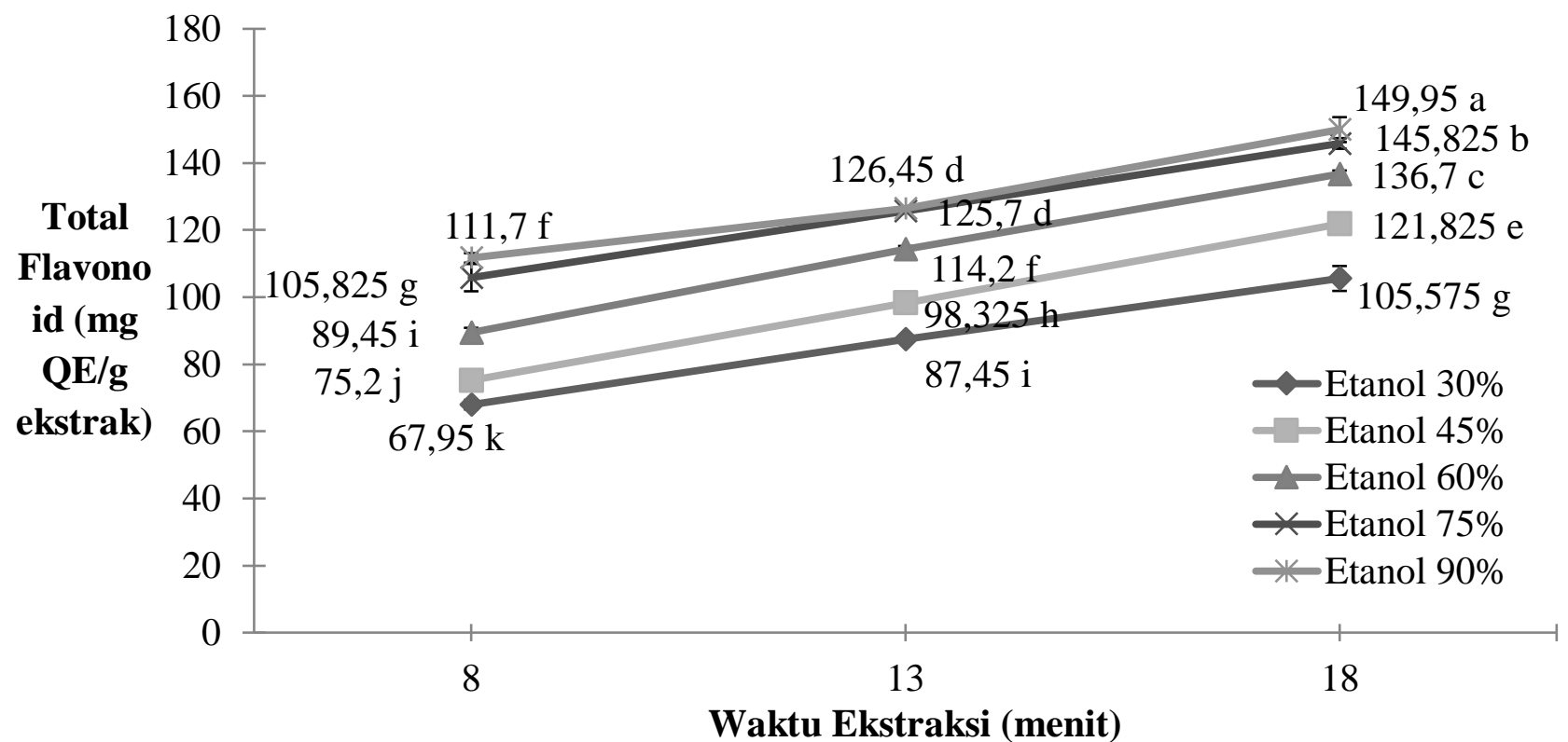

Gambar 4. Total flavonoid ekstrak rambut jagung (mg QE/g ekstrak)

Keterangan: Notasi yang sama menunjukkan perlakuan tidak berbeda nyata $(\mathrm{P}>0,05)$

Gambar 4 menyatakan bahwa total flavonoid tertinggi diperoleh dari ekstraksi dengan etanol 90\% dengan waktu 18 menit yaitu 149,95 mg QE/g ekstrak, sedangkan total flavonoid terendah diperoleh dari ekstraksi dengan etanol 30\% dengan waktu 8 menit yaitu 67,95 mg QE/g ekstrak. Hasil penelitian menyatakan bahwa semakin lama waktu ekstraksi dan semakin tinggi konsentrasi etanol maka total flavonoid juga semakin meningkat.

Kenaikan waktu proses ekstraksi yang digunakan akan meningkatkan penetrasi pelarut ke dalam bahan baku. Ibrahim et al., 
(2015) menyatakan bahwa waktu ekstraksi yang terlalu singkat akan menyebabkan tidak semua senyawa dapat terekstrak dari bahan. Winata dan Yunianta., (2015) menyatakan bahwa semakin lama waktu ekstraksi, kuantitas bahan yang terekstrak juga semakin meningkat dikarenakan kesempatan untuk bersentuhan antara bahan dengan pelarut semakin besar sehingga hasilnya akan bertambah sampai titik jenuh larutan. Hasil penelitian menyatakan bahwa konsentrasi etanol yang meningkat akan meningkatkan total flavonoid. Purwanto et al., (2014) menyatakan bahwa polaritas pelarut sangat mempengaruhi hasil ekstraksi bahan karena senyawa target yang akan diekstrak akan mudah larut pada tingkat polaritas yang sama.

\begin{abstract}
Aktivitas Antioksidan
Hasil sidik ragam menunjukkan bahwa interaksi waktu ekstraksi dan konsentrasi etanol dalam ekstraksi rambut jagung berpengaruh sangat nyata $(\mathrm{P}<0,01)$ terhadap aktivitas antioksidan. Grafik hasil interaksi antara konsentrasi etanol dan waktu ekstraksi terhadap aktivitas antioksidan pada ekstrak rambut jagung dapat dilihat pada Gambar 5.
\end{abstract}

\section{Aktivitas Antioksidan}

(\%)

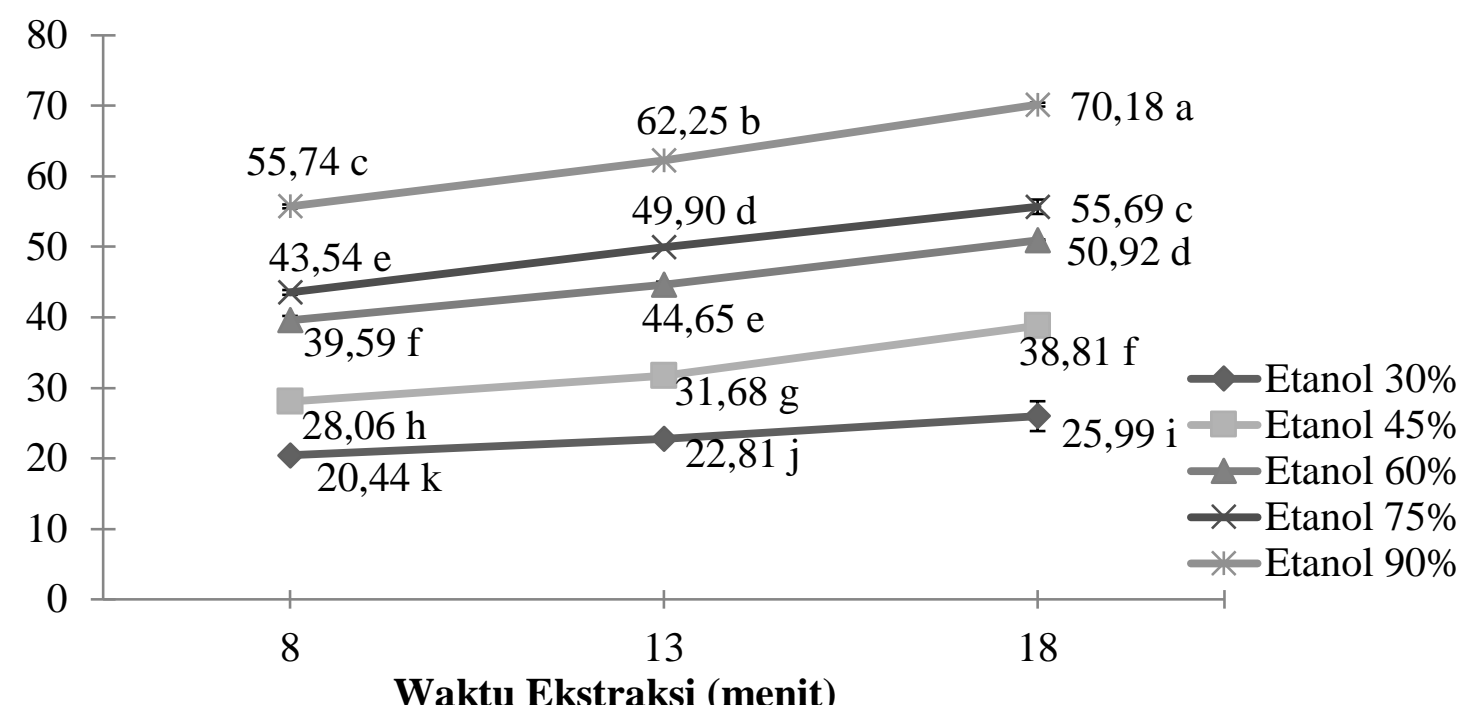

Waktu Ekstraksi (menit)

Gambar 5. Aktivitas antioksidan ekstrak rambut jagung (\%)

Keterangan: Notasi yang sama menunjukkan perlakuan tidak berbeda nyata $(\mathrm{P}>0,05)$

Gambar 5 menunjukkan bahwa aktivitas antioksidan tertinggi diperoleh dari ekstraksi dengan etanol $90 \%$ dengan waktu 18 menit yaitu $70,18 \%$, sedangkan aktivitas antioksidan terendah diperoleh dari ekstraksi dengan etanol $30 \%$ dengan waktu 8 menit yaitu $20,44 \%$. Semakin lama waktu ekstraksi dan semakin tinggi konsentrasi etanol maka semakin tinggi juga aktivitas antioksidan yang dihasilkan. Waktu ekstraksi terbaik pada penelitian ini adalah 18 menit. Hal serupa juga dilaporkan oleh Graziani et al., (2010) yang menyatakan bahwa waktu 18 menit juga merupakan waktu optimum untuk memperoleh aktivitas antioksidan terbaik pada Cinnamomum zeylanicum. Aktivitas antioksidan dipengaruhi oleh meningkatnya total fenol dan flavonoid pada bahan sehingga semakin tinggi total fenol dan flavonoid maka semakin tinggi juga aktivitas antioksidannya sesuai dengan Gambar 3, 4 dan 5.

Hubungan antara kandungan fenol total dan total flavonoid terhadap aktivitas antioksidan memiliki kolerasi yang kuat. Angkasa dan Suleman (2012) menyatakan bahwa kandungan total fenol pada daun Hantap (Sterculia coccinea. Jack) memiliki nilai korelasi sebesar $99 \%$ terhadap aktivitas 
antioksidannya. Hasil penelitian Kemit et al.,(2016) menyatakan bahwa total flavonoid juga memiliki korelasi positif dengan aktivitas antioksidan pada ekstrak daun alpukat (Persea Americana Mill) dengan nilai ratarata koefisien korelasi $\left(\mathrm{R}^{2}\right)$ sebesar 0,955.

Berdasarkan hasil analisis aktivitas antioksidan pada ekstrak rambut jagung diperoleh perlakuan terbaik untuk ekstraksi yaitu dengan waktu 18 menit menggunakan pelarut etanol 90\%. Berdasarkan hasil tersebut maka dilakukan uji lanjut yaitu penentuan $\mathrm{IC}_{50}$. Hasil pengujian aktivitas antioksidan ekstrak rambut jagung dalam beberapa konsentrasi dapat dilihat pada Gambar 6.

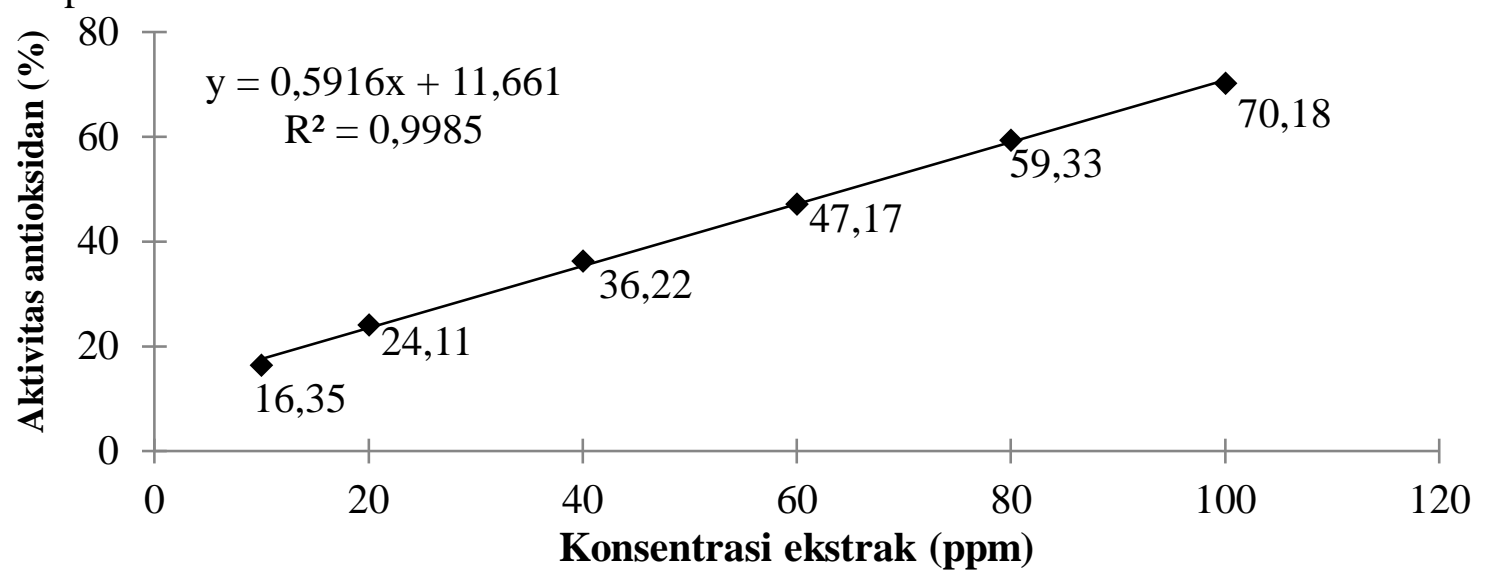

Gambar 6. Grafik hubungan antara aktivitas antioksidan dan konsentrasi ekstrak

Gambar 6 menunjukkan interaksi antara konsentrasi ekstrak (x) dengan aktivitas antioksidan (y) yang diperoleh. Diketahui bahwa semakin tinggi konsentrasi ekstrak maka semakin tinggi juga aktivitas antioksidannya. Analisis regresi linier yang diperoleh dari grafik tersebut menyatakan persamaan $\mathrm{y}=0,5915 \mathrm{x}+11,661$ dengan $\mathrm{IC}_{50}$ sebesar 64,81 ppm.

\section{KESIMPULAN DAN SARAN}

\section{Kesimpulan}

Berdasarkan hasil penelitian yang telah diperoleh, maka dapat disimpulkan beberapa hal sebagai berikut :

1. Interaksi waktu ekstraksi dan konsentrasi etanol berpengaruh sangat nyata terhadap rendemen, total fenol, total flavonoid, dan aktivitas antioksidan ekstrak rambut jagung.

2. Hasil penelitian menunjukkan bahwa waktu ekstraksi terbaik menggunakan metode Microwave Assisted Extraction (MAE) adalah 18 menit dengan pelarut etanol 90\%. Berdasarkan perlakuan terbaik tersebut didapatkan jumlah rendemen, total fenol, total flavonoid, dan aktivitas antioksidan masing-masing sebesar 24,54\%, 159,65 mg GAE/g ekstrak, 149,95 mg QE/g ekstrak, dan $70,18 \%$. Nilai $\mathrm{IC}_{50}$ adalah sebesar 64,81 ppm.

\section{Saran}

Perlu dilakukan penelitian yang mengkaji pengaruh konsentrasi etanol yang lebih tinggi dan waktu ekstraksi yang lebih lama untuk menghasilkan ekstrak rambut jagung dengan aktivitas antioksidan yang lebih tinggi.

\section{DAFTAR PUSTAKA}


Anonimus. 2012. Produksi padi, jagung, dan kedelai. Badan Pusat Statistik. www.bps.go.id/getfile.php?news=938/ diakses tanggal: 23 Juni 2018.

Angkasa, D dan A. Sulaeman. 2012. Pengembangan Minuman Fungsional Sumber Serat dan Antioksidan dari Daun Hantap (Sterculia oblongata $R$. Brown.). Skripsi. Tidak dipublikasikan. Departemen Gizi Masyarakat Institut Pertanian Bogor, Bogor.

Bushman, B.S. 2002. The Genetic Basis of Chlorogenic Acid Synthesis in Maize.PhD Dissertation University of Missouri-Columbia, USA.

Faesal. 2013. Pengolahan Limbah Tanaman Jagung Untuk Pakan Ternak Sapi Potong. Prosiding Seminar Nasional Inovasi Teknologi Pertanian. Badan Litbang Pertanian, Jakarta

Graziani, G., M. Galo, R. Ferracane, A. Ritieni dan V. Fogliano. 2010. Microwave assisted extraction of phenolic compounds from four different spices. Molecules Journal 15:6365-6374

Handayani, D., A. Mun'im dan A.S. Ranti. 2014. Optimation of green tea waste extraction using microwave assisted extraction to yield green tea extract. Traditional Medicine Journal 19(1):29-35

Herbie, T. 2015. Kitab Tanaman Berkhasiat Obat-226 Tumbuhan Obat untuk Penyembuhan Penyakit dan Kebugaran Tubuh. Octopus Publishing House, Yogyakarta

Hu, Q. L. and Z. Deng. 2011. Protective effects of flavonoids from corn silk on oxidative stress induced by exhaustive exercise in mice. African Journal of Biotechnology 10: 3163-3167

Ince, A.E., S. Sahin dan G.S. Servet. 2013. Extraction of phenolic compounds from melissa using microwave and ultrasound. Turk Journal Agritech $37: 69: 75$.

Jain, T., V. Jain, R. Pandey, A. Vyas dan S. Shukla. 2009. Microwave assisted extraction for phytoconstituents - an overview. Asian Journal Research Chemistry 2: 19-25.

Kemit, N., I.W.R. Widarta, dan K.A. Nocianitri. 2015. Pengaruh jenis pelarut dan waktu maserasi terhadap kandungan senyawa flavonoid dan aktivitas antioksidan ekstrak daun alpukat (Persea Americana Mill). Jurnal ITEPA 5(2): 130-141

Kirk, R.E. dan D.F. Othmer. 1998. Encyclopedia of Chemical Engineering Technology. The Interscience Publisher Division of John Wiley and Sons Inc, New York.

Kojic, A.B., P. Mirela, T. Srecko, K. Stela, M. Ibrahim, B. Mate dan V. Darko. 2011. Effect of extraction conditions on the extractability of phenolic compounds from lyophilised fig fruits (Ficus carcia L). Journal Food Nutrition Science 61(3): 195-199.

Langat, M. K. 2011. Chemical Constituents of East European Forest Species. Book of Extended Extracts, Kenya

Liu, J., C. Wang, Z. Wang, C. Zhang, S. Lu dan J. Liu. 2011. The antioxidant and free radical scavenging activities of the extract and fraction from cornsilk (Zea mays L.) and related flavone glycosides. Food Chemistry 126(1): 261-269 
Sarepoua, E., R. Tangwochai, B. Suriharn dan K. Lertrat. 2013. Relationship between phytochemicals and antioxidant activity in corn silk. International Food Research Journal 20(5): 20732079

Sompong, R., S. Siebenhandl-Ehn, G. Linsberger-Martin dan G.E. Berghofer. 2011. Physicochemical and antioxidative properties of red and black rice varieties from Thailand, China and Sri Lanka. Food Chemistry 124: 132-140.

Steel, R.G.D. dan J.H. Torrie. 1993. Prinsip dan Prosedur Statistik Suatu Pendekatan Biometric. Penerjemah Bambang Sumantri. PT. Gramedia Pustaka Utama, Jakarta.

Wang, C., T. Zhang, J. Liu, S. Lu, C. Zhang, E. Wang, Z. Wang, Y. Zhang dan J. Liu. 2011. Subchronic toxicity study of cornsilk with rats. Journal of Ethnopharmacology 137: 36-43.

Widarta, I.W.R. dan I.W. Arnata. 2017. Extraction of bioactive compounds from avocado leaves by sonication at various solvent types and concentration. Agritech Journal 37(2):158-166 